\title{
14 RESULTS FROM CHARACTERISATION OF LANDFILL LEACHATES AND RELATED EFFLUENTS
}

\author{
Olof Cerne \\ Christian Junestedt \\ IVL Swedish Environmental Research Institute Ltd, Stockholm, Sweden
}

\begin{abstract}
A number of landfill leachates and related effluents has been characterised in research projects from 1996 till today. Up to 400 parameters has been analysed in samples from 30 sites. A database based on the results will be available in the beginning of 2002 on www.ivl.se. The samples of runoff water from waste segregation areas shows higher concentrations of some compounds compared to landfill leachates.
\end{abstract}

\section{INTRODUCTION}

A number of landfill leachates and related effluents has been characterised in research projects from 1996 till today. Grab samples of both water and sediment has been analysed. The parameters analysed are general characteristics, such as COD, BOD and N-ammonium, organic sum parameters such as EGOM and EOX, organic compounds, metal-organic compounds, metals, other elements, toxicity and hormone disrupting effects.

\section{BACKGROUND}

Details about the investigated sites, sampling methods etc concerning the work until 1999 are described in previously published reports (Öman et al, 2000). Details concerning the work from 2000 until now will be published later.

\section{RESULTS FROM CHARACTERISATION}

Up to 400 parameters has been analysed in samples from 30 sites. Only a small fraction of the results is presented in this paper. In table 1 some results are presented. 
KALMAR ECO-TECH'01

Leachate and Wastewater Treatment with High-Tech and Natural systems

KALMAR, SWEDEN, November 26-28, 2001

\begin{tabular}{|c|c|c|c|c|c|}
\hline Parameters & $\begin{array}{l}\text { Conc. in } \\
\text { landfill } \\
\text { leachates }\end{array}$ & $\begin{array}{l}\text { Average } \\
\text { conc., } \\
\text { (number of } \\
\text { sites in } \\
\text { brackets) }\end{array}$ & $\begin{array}{l}\text { Concentration } \\
\text { in runoff water } \\
\text { from waste } \\
\text { segregation } \\
\text { area 1 }\end{array}$ & $\begin{array}{l}\text { Concentration } \\
\text { in runoff water } \\
\text { from waste } \\
\text { segregation } \\
\text { area 2 }\end{array}$ & Comments \\
\hline Flow & & $\begin{array}{l}\text { Not } \\
\text { available }\end{array}$ & Not available & $\begin{array}{l}20000 \\
\text { m3/year }\end{array}$ & \\
\hline $\mathrm{TOC}(\mathrm{mg} / \mathrm{l})$ & $49-490$ & $150,(21)$ & 1900 & 90 & \\
\hline $\operatorname{COD}(\mathrm{mg} / \mathrm{l})$ & $160-1300$ & $640,(19)$ & 8000 & 310 & \\
\hline Chloride $(\mathrm{mg} / \mathrm{l})$ & $310-4900$ & $1500,(21)$ & 1300 & 90 & \\
\hline $\mathrm{BOD}(\mathrm{mg} / \mathrm{l})$ & $3-110$ & $30,(18)$ & 3400 & 90 & \\
\hline $\mathrm{N}$-tot $(\mathrm{mg} / \mathrm{l})$ & $15-870$ & $270,(22)$ & 120 & 10 & \\
\hline $\mathrm{N}$-ammonia $(\mathrm{mg} / \mathrm{l})$ & $0-110$ & $60,(24)$ & 0,2 & 0,3 & \\
\hline Nonylphenol $(\mu \mathrm{g} / \mathrm{l})$ & $0-17$ & $2,(14)$ & Not analysed & 4,5 & \\
\hline $\begin{array}{l}\text { Nonylphenol } \\
\text { monoetoxylate }(\mu \mathrm{g} / \mathrm{l})\end{array}$ & $0-15$ & $7,(8)$ & Not analysed & 14 & \\
\hline $\begin{array}{l}\text { Sum nonylphenol } \\
\text { etoxylate }(\mu \mathrm{g} / \mathrm{l})\end{array}$ & Not available & $\begin{array}{l}\text { Not } \\
\text { available }\end{array}$ & 33 & Not available & \\
\hline $\begin{array}{l}\text { Diethyl phthalate } \\
(\mu \mathrm{g} / \mathrm{l})\end{array}$ & $0-5$ & $0,8,(30)$ & 49 & 2,5 & \\
\hline $\begin{array}{l}\text { Pentabromo } \\
\text { diphenylether }(\mu \mathrm{g} / \mathrm{l})\end{array}$ & $0-0,07$ & $0,03,(9)$ & 0,66 & 0,01 & $\begin{array}{l}\text { Bromated flame } \\
\text { retardant }\end{array}$ \\
\hline $\begin{array}{l}2,4-\mathrm{DP} \text {, dichloroprop } \\
(\mu \mathrm{g} / \mathrm{l})\end{array}$ & $0-8$ & $1,2,(25)$ & 7,3 & 1,7 & $\begin{array}{l}\text { Pesticide, one of } \\
\text { the } 8 \text { fenoxi acid } \\
\text { that is often found } \\
\text { in landfill leachates }\end{array}$ \\
\hline TBT, tributyl tin $(\mu \mathrm{g} / \mathrm{l})$ & $0-0,02$ & $0,003,(12)$ & 0,41 & 0,27 & \\
\hline Methylmercury (ng/l) & $0-0,9$ & $0,5,(12)$ & 0,7 & Not analysed & \\
\hline
\end{tabular}

Table 1. Some results of characterisation of leachates and runoff waters from waste segregation areas. The number of sampled sites are indicated in brackets

\section{DATABASE}

The large number of data collected in these projects will be published in a database on the internet. The database will also contain data on storm water from air field, ground water and treated municipal waste water. The database will also contain data research organisations others than IVL. The database should be available in the beginning of 2002 on www.ivl.se.

\section{DISCUSSION}

\section{The limitations of grab samples}

It's important to understand the limitations of the grab samples. We don't know in what extent the character of the landfill leachates are changing over time. Probably the character of runoff water from waste segregation areas is changing more than the leachates. The purpuse of our investigations has however mainly been to identify specific compounds.

Most of the landfill leachate sampling are however made in the leachate ponds. This makes the samples more representative compared to grab samples taken in tubes or ditches. 
The samples are analysed as single samples, mostly without blank samples. Although the use of our samling techniques reduce the contamination risks we still can get wrong analyse results from the laboratory. To get more reliable results it's necessary to analyse duplicates, blank samples and to run the same sample at different laboratories. This is however very expencive.

\section{Runoff water from waste segregation area}

The effluents of nunoff water from waste segregation areas are of special interest. The results from the analysis of the two grab samples are not easy to interpret. However the samples shows higher concentrations of some compounds compared to landfill leachates. The volumes of runoff water are today generally smaller than the volumes of landfill leachates. However, the changes in the waste management sector could imply larger volumes of wastes at open segregation areas. These areas often have no collecting and treatment systems for the runoff water.

\section{The leachates of tomorrow}

Another interesting issue is tomorrows landfill leachates. How will the changes in the waste management sector affect the volumes and character of the leachates? The changes in the waste management sector could imply larger volumes of segregated wastes in cell deposits and less organic content on the landfills.

\section{REFERENCES}

1. Öman C et al. (2000). Handbok för lakvattenbedömning. Rapport B 1354. IVL Svenska Miljöinstitutet AB, Stockholm. 